\title{
Potensi budidaya lebah madu sebagai harapan di tengah pandemi Covid-19
}

\author{
Andhika Silva Yunianto*, \& Syasri Jannetta \\ Balai Penelitian dan Pengembangan Teknologi Serat Tanaman Hutan \\ *andhikasilva@gmail.com
}

\begin{abstract}
Abstrak. Lebih dari tiga perempat penduduk Indonesia menggantungkan hidupnya dari hasil hutan baik kayu maupun non-kayu. Belum memperhatikan pengelolaan hutan yang lestari di tengarai menjadi penyebab kerusakan hutan semakin parah dari tahun ke tahun. COVID-19 mengakibatkan banyak masyarakat kehilangan mata pencaharian. Apabila tidak ditanggulangi, hutan yang tersisa akan semakin mengalami kerusakan karena desakan ekonomi memaksa masyarakat sekitar kawasan untuk melakukan deforestasi. Budidaya lebah madu merupakan salah satu upaya alternatif mata pencaharian masyarakat di sekitar kawasan hutan. Hal ini didukung oleh permintaan madu skala nasional sangat tinggi, namun berbanding terbalik dengan produksi yang sangat minim. Hasil menunjukkan bahwa budidaya lebah Trigona $S p$ sangat memungkinkan untuk dilakukan di kawasan pemukiman, zona penyangga dan zona tradisional sehingga mampu menjadi sumber pendapatan alternatif bagi masyarakat sekaligus menjaga kelestarian ekosistem lingkungan. Kurun waktu 4 bulan, panen madu dari kawasan pemukiman sebanyak 1.75 liter dari 10 koloni, zona penyangga sebanyak 4.3 liter dari 13 koloni, dan zona tradisional sebanyak 10.65 liter dari 44 koloni. Revitalisasi perlu dilakukan di zona penyangga untuk memberikan perlindungan tambahan bagi kawasan dan bermanfaat bagi masyarakat.
\end{abstract}

Kata kunci: budidaya lebah, zona penyangga, zona tradisional, lebah madu, mata pencaharian alternatif

\begin{abstract}
More than three-quarters of Indonesia population depend on forest products, both timber and non-timber. Having not paying attention to sustainable forest management is believed to be the cause of forest damage getting worse in every year. COVID-19 made many people lose their livelihoods. If not anticipated, the remaining forest will suffer more damaged due to economic pressure forcing by communities around the area to doing deforestation. Honey bee cultivation is an alternative way of livelihoods for communities around forest areas. This is supported by the very high national scale demand for honey, but it is very inversely proportional with the low production of honey. The results showed that it is possible to cultivate Trigona Sp. bees in residential areas, buffer zone and traditional zone, so that it can be used as alternative source of income for the surrounding community, while preserving the environmental ecosystem. Within 4 months, honey yields from residential areas are 1.75 liters from 10 colonies, in the buffer zone as much as 4.3 liters from 13 colonies, and in the traditional zone as much as 10.65 liters from 44 colonies. Revitalization needs to be carried out in the buffer zone to provide additional protection for the area and benefit the community.
\end{abstract}

Keywords: beekeeping, buffer zone, traditional zone, honey bee, alternative livelihoods

To cite this article: Yunianto, A. S., \& S. Jannetta. 2020. Potensi budidaya lebah madu sebagai harapan di tengah pandemi Covid-19. Unri Conference Series: Community Engagement 2: 192-200.

https://doi.org/10.31258/unricsce.2.192-200

(C) 2020 Authors

Peer-review under responsibility of the organizing committee of Seminar Nasional Pemberdayaan Masyarakat 2020 


\section{PENDAHULUAN}

Masyarakat sekitar kawasan hutan merupakan masyarakat yang bermukim atau bertempat tinggal di dalam dan di sekitar kawasan hutan, baik mengelompok dengan jumlah beberapa keluarga saja maupun yang telah membentuk kesatuan seperti suku, dusun maupun desa dengan interaksi yang cukup kuat antara kehidupan sosial, ekonomi dan budaya masyarakat dengan lingkungannya.

Saat ini, diperkirakan lebih dari tiga perempat penduduk Indonesia menggantungkan hidupnya dari hasil hutan. Hal ini dikarenakan mereka bermukim di sekitar kawasan hutan. Dari tahun ke tahun kerusakan hutan yang terjadi di Indonesia semakin parah dan meluas. Adapun hutan yang tersisa tak luput dari keterancaman seperti alih fungsi kawasan hutan menjadi perkebunan, pemukiman, pembalakan liar, dll (Baskoro et al., 2019).

Berdasarkan data dari Kementerian Lingkungan Hidup dan Kehutanan (KLHK), saat ini terdapat 14 juta hektar lahan kritis di Indonesia (PPID KLHK, 2018). Kebakaran hutan dan lahan (karhutla) yang semakin marak belakangan ini turut menambah luas lahan kritis. Karhutla yang terjadi pada Januari hingga Agustus 2019 mengakibatkan 328.724 hektar lahan terbakar di seluruh Indonesia (Anonim, 2019). Adapun kejadian karhutla terbesar salah satunya berada di Propinsi Riau yang mencapai 49.266 hektar (Ekarina, 2019).

Pandemi COVID-19 yang terjadi akhir-akhir ini, membuat sebagian besar masyarakat kehilangan mata pencaharian utamanya. Bagi masyarakat yang tinggal di sekitar kawasan hutan, dengan kebutuhan akan lahan yang tinggi, tentunya hal ini memunculkan kekhawatiran akan terjadinya alih fungsi kawasan. Diperlukan upaya dengan mempertimbangkan akar permasalahan, keterwakilan aspek sosial budaya serta kebiasaan masyarakat setempat (Matatula, 2009).

Keseharian masyarakat sekitar kawasan hutan menggantungkan hidupnya dari hasil hutan baik kayu maupun non-kayu. Bagi masyarakat yang tinggal di dalam kawasan, dengan akses yang sulit dijangkau, mereka menggunakan kayu untuk keperluan bahan bakar memasak. Bahkan ada sebagian besar masyarakat yang menebang dan menjual kayu tersebut untuk mencukupi perekonomian mereka.

Padahal, apabila dimanfaatkan secara arif dan bijaksana, sumberdaya hutan non-kayu akan memberikan nilai ekonomi yang tinggi bagi masyarakat sekitar kawasan hutan tanpa perlu merusak kawasan hutan tersebut. Hasil hutan non-kayu tersebut merupakan bahan-bahan atau komoditas dari seluruh materi biologis termasuk jasa lingkungan yang diperoleh dari dalam kawasan hutan tanpa harus menebang pohon, seperti rotan, bambu, madu, dll.

Untuk menanggulangi terjadinya kerusakan hutan yang semakin parah, pihak KLHK menerapkan kebijakan yang melibatkan masyarakat langsung dalam pengelolaan kawasan hutan. Hal ini dimaksudkan agar masyarakat memiliki peranan yang sama serta tanggung jawab langsung dalam pengelolaan kawasan hutan guna kelestarian kawasan hutan.

Berbagai macam upaya dapat dilakukan seperti pelibatan masyarakat dalam pengelolaan kawasan hutan (Ulya et al., 2016). Budidaya lebah madu dapat dijadikan sebagai salah satu upaya rehabilitasi kawasan hutan. Selain itu, budidaya lebah madu juga dapat menjadi mata pencaharian alternatif masyarakat terutama yang bermukim disekitar kawasan hutan. Kegiatan budidaya lebah madu dapat menarik peran aktif masyarakat dalam menjaga kelestarian lingkungan.

Madu merupakan salah satu produk Hasil Hutan Bukan Kayu (HHBK) yang menjadi primadona di masyarakat dengan berbagai macam manfaatnya. Salah satu manfaat madu adalah untuk meningkatkan imunitas di tengah pandemi COVID-19. Produksi madu nasional masih tergolong rendah dan cenderung mengalami penurunan tiap tahunnya, berbanding terbalik dengan potensi pasar dalam negeri yang sangat besar. Penurunan produksi madu membuat Indonesia mengimpor madu dari Negara lain untuk memenuhi permintaan pasar dalam negeri (Novandra \& Widnyana, 2013). Rata-rata produksi madu di seluruh Indonesia sekitar 4.000 ton tiap tahunnya, dan dari produksi tersebut sekitar $75 \%$ dihasilkan dari perburuan madu liar di hutan (Widiarti \& Kuntadi, 2012). Apabila dibandingkan antara produksi madu nasional yang terus menurun tiap tahunnya, kebutuhan madu nasional yang sangat tinggi dan kondisi hutan di Indonesia yang digolongkan kritis, kondisi demikian merupakan peluang bagi masyarakat untuk melakukan budidaya lebah madu.

\section{METODE PENERAPAN}

\section{Sasaran Pengabdian}

Sasaran pengabdian ini adalah masyarakat yang tinggal di sekitar kawasan hutan dengan membagi kedalam tiga zona, yaitu zona tradisional, zona penyangga dan zona pemukiman dan tergabung ke dalam wadah kelompok tani. Dalam pelaksanaan pengabdian melibatkan berbagai pihak, seperti pihak pengelola kawasan, pemerintah desa, tenaga penyuluh lapangan, serta tim pengajar. 
Kegiatan ini dilakukan di kawasan taman nasional bukit tiga puluh (tnbt), di kabupaten indragiri hulu dan indragiri hilir, yaitu desa rantau langsat, keritang dan selensen yang termasuk ke dalam desa penyangga kawasan tnbt serta desa nunusan, sadan, air bomban, bengayauan dan siambul yang termasuk dalam zona tradisional tnbt, dan di lingkungan balai penelitian dan pengembangan teknologi serat tanaman hutan (bp2tsth) kuok di kabupaten kampar.

Metode Kegiatan

Permasalahan bahwa terdapat potensi alternatif mata pencaharian masyarakat disekitar kawasan hutan yang belum dipahami oleh masyarakat karena ketidaktahuan dalam mengelola sumberdaya tersebut dapat diselesaikan menggunakan metode deskriptif kualitatif dengan pendekatan teknik PRA (Participatory Rural Appraisal) seperti pemetaan kawasan, penelusuran lokasi, analisis mata pencaharian dan wawancara semi terstruktur. Sedangkan upaya yang dapat dilakukan dalam upaya pemberdayaan masyarakat dilakukan dengan memberikan pendidikan dan pelatihan serta pendampingan secara intensif.

\section{HASIL DAN KETERCAPAIAN}

\section{a. Karakteristik masyarakat dan potensi di tiga zona pemanfaatan}

Kegiatan pengabdian masyarakat ini dilakukan di tiga zona pemanfaatan, yaitu zona tradisional dan zona penyangga yang berada di TNBT serta zona pemukiman yang berada di Kuok, Kampar. Masing-masing zona memiliki karakteristik masyarakat dan lingkungan yang berbeda.

Masyarakat tradisional yang tinggal di dalam kawasan terdiri dari Suku Talang Mamak, Melayu Tua dan Anak Dalam (Rimba). Masyarakat yang tinggal di dalam zona tradisional memiliki kebiasaan/keseharian yang melekat seperti berburu, meramu makanan, mengumpulkan hasil hutan dan berladang. Disela berladang, mereka juga mencari HHBK seperti Rotan Jernang dan Klukup, Pinang, Durian, Madu Hutan, Burung, Labilabi, dll. Sumber pendapatan masyarakat zona tradisional berasal dari hasil kebun karet, pengumpulan HHBK khususnya Jernang dan kegiatan lainnya seperti berdagang.

Masyarakat yang terdapat di zona penyangga di Kecamatan Kemuning merupakan suku Melayu, Jawa yang merupakan masyarakat transmigrasi dan pendatang dari Sumatera Utara. Sebagian besar penduduk memiliki mata pencaharian di sektor perkebunan dan kehutanan. Mata pencaharian utama masyarakat asli desa penyangga berasal dari sektor perkebunan dengan melakukan alih fungsi lahan hutan menjadi perkebunan karet yang dipelihara secara tidak intensif. Sedangkan aktivitas pertanian penduduk pendatang yang umumnya memiliki modal uang memadai, lebih memilih untuk membuka usaha perkebunan kelapa sawit. Namun, kegiatan pertanian utama sebagian besar penduduk asli dan penduduk pendatang adalah berkebun kelapa sawit, hanya sebagian kecil saja yang mengelola kebun karet (Anonim, 2006).

Sebagian besar penduduk di zona pemukiman memiliki mata pencaharian di sektor pertanian, perkebunan dan kehutanan. Di sektor perkebunan, tanaman kelapa sawit dan karet banyak dibudidayakan oleh masyarakat. Masyarakat Kuok mayoritas adalah orang Minangkabau yang menyebut diri mereka sebagai Ughang Ocu dengan persukuan Domo, Malayu, Piliang, dll. Terdapat juga sedikit etnis Melayu, Jawa dan Batak yang sudah berbaur (Ali et al., 2019).

Lebah dan tanaman memiliki satu ketergantungan yang saling menguntungkan. Lebah dapat membantu tanaman dalam melakukan penyerbukan tanpa merusak organ-organ yang terdapat pada tanaman. Tanaman memberikan pakan yang dibutuhkan oleh lebah berupa nektar dan polen untuk dijadikan sebagai madu. Di daerah tropis seperti Indonesia lebah dapat berkembang biak dengan baik dan produktif sepanjang tahun karena ketersediaan sumber pakan yang berkelanjutan. Keberadaan lebah didukung dengan adanya sumber pakan yang tersedia di lokasi tersebut. 
Tabel 1. Jenis tanaman pakan lebah di tiga zona pemanfaatan

\begin{tabular}{|c|c|c|c|c|c|}
\hline \multirow{2}{*}{ No. } & \multicolumn{2}{|r|}{$\begin{array}{l}\text { Jenis Tanaman } \\
\text { (Type of plants) }\end{array}$} & \multicolumn{3}{|c|}{$\begin{array}{c}\text { Bagian yang diambil } \\
\text { (Extracted parts) }\end{array}$} \\
\hline & $\begin{array}{l}\text { Nama Lokal } \\
\text { (Local name) }\end{array}$ & $\begin{array}{c}\text { Nama Latin } \\
(\text { Scientific name })\end{array}$ & $\begin{array}{l}\text { Nektar } \\
\text { (Nectar) }\end{array}$ & $\begin{array}{c}\text { Polen } \\
\text { (Pollen) }\end{array}$ & $\begin{array}{l}\text { Getah } \\
\text { (Sap) }\end{array}$ \\
\hline 1 & Lawang & Illicium verum & - & - & - \\
\hline 2 & Gmelina & Gmelina arborea & - & - & - \\
\hline 3 & Durian $^{1}$ & Durio zibethinus & $\mathrm{v}$ & $\mathrm{v}$ & - \\
\hline 4 & Petai $^{1}$ & Parkia speciosa & $\mathrm{v}$ & $\mathrm{v}$ & - \\
\hline 5 & Kasai $^{1}$ & Pometia pinnata & $\mathrm{v}$ & $\mathrm{v}$ & - \\
\hline 6 & Pulai $^{1}$ & Alstonia scholaris & $\mathrm{v}$ & $\mathrm{v}$ & $\mathrm{v}$ \\
\hline 7 & Jernang $^{1}$ & Daemonorops draco & - & - & - \\
\hline 8 & Pinang ${ }^{1}$ & Areca catechu & $\mathrm{v}$ & $\mathrm{v}$ & - \\
\hline 9 & Mahang ${ }^{1}$ & Macaranga & $\mathrm{v}$ & - & - \\
\hline 10 & Bintaro & Cerbera manghas & - & - & - \\
\hline 11 & Kulim $^{1}$ & Scorodocarpus borneensis & - & - & - \\
\hline 12 & Melati & Jasminum sambac & - & - & - \\
\hline 13 & Tanjung & Mimusops elengi & - & - & - \\
\hline 14 & Anggrek ${ }^{1}$ & Dipodium pictum & $\mathrm{v}$ & - & - \\
\hline 15 & Keruing $^{1}$ & Dipterocarpus & $\mathrm{v}$ & - & $\mathrm{v}$ \\
\hline 16 & Rengas $^{1}$ & Gluta renghas & - & - & $\mathrm{v}$ \\
\hline 17 & $\operatorname{Ramin}^{1}$ & Gonystylus bancanus & - & - & - \\
\hline 18 & $\mathrm{Jambu}^{1}$ & Syzygium aquеum & $\mathrm{v}$ & $\mathrm{v}$ & - \\
\hline 19 & Pisang $^{1}$ & Musa Spp & $\mathrm{v}$ & $\mathrm{v}$ & - \\
\hline 20 & Rambutan $^{1}$ & Naphelium lappaceum & $\mathrm{v}$ & $\mathrm{v}$ & - \\
\hline 21 & Vanili $^{1}$ & Vanilla planifolia & - & - & - \\
\hline 22 & Duku $^{1}$ & Lansium domesticum & $\mathrm{v}$ & - & - \\
\hline 23 & Terentang $^{1}$ & Campnosperma & - & - & - \\
\hline 24 & Belimbing $^{1}$ & Averrhoa carambola & $\mathrm{v}$ & $\mathrm{v}$ & - \\
\hline 25 & Dadap $^{1}$ & Erythrina variegate & $\mathrm{v}$ & $\mathrm{v}$ & - \\
\hline 26 & Jeruk Nipis ${ }^{1}$ & Citrus aurantiifolia & $\mathrm{v}$ & $\mathrm{v}$ & - \\
\hline 27 & Pepaya $^{1}$ & Carica papaya & $\mathrm{v}$ & $\mathrm{v}$ & - \\
\hline 28 & Manggis ${ }^{1}$ & Garcinia mangostana & $\mathrm{v}$ & - & $\mathrm{v}$ \\
\hline 29 & Terong ${ }^{1}$ & Solanum melongena & $\mathrm{v}$ & $\mathrm{v}$ & - \\
\hline 30 & Mangga $^{1}$ & Mangifera indica & $\mathrm{v}$ & $\mathrm{v}$ & $\mathrm{v}$ \\
\hline 31 & Kelapa $^{1}$ & Cocos nucifera & $\mathrm{v}$ & $\mathrm{v}$ & - \\
\hline 32 & Kelapa Sawit ${ }^{1}$ & Elaeis guineensis Jacq. & - & $\mathrm{v}$ & - \\
\hline 33 & Karet $^{1}$ & Hevea brasiliensis & $\mathrm{v}$ & - & $\mathrm{v}$ \\
\hline
\end{tabular}




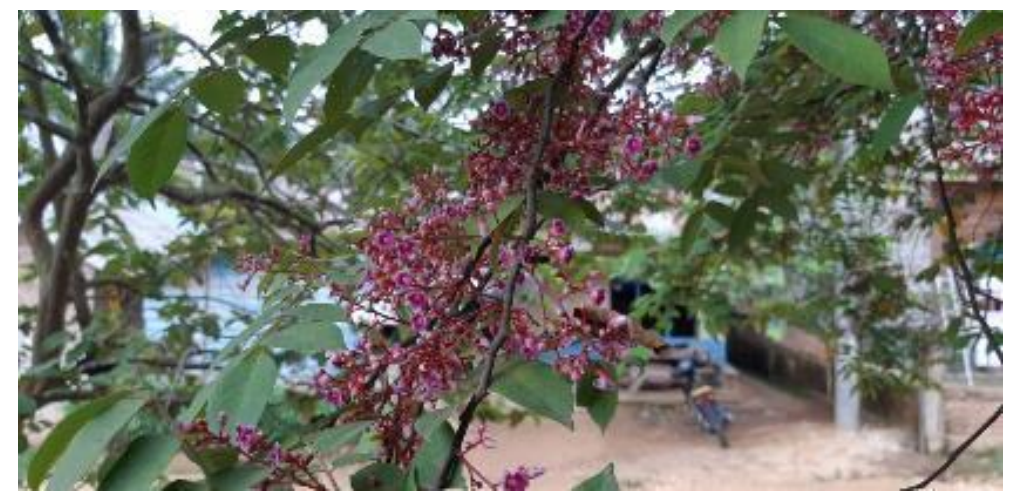

Gambar 1. Lebah menghinggapi bunga yang terdapat di pemukiman masyarakat

Berdasarkan tabel 1, diketahui bahwa sebagian besar jenis tanaman yang ada di tiga zona pemanfaatan merupakan tanaman sumber pakan lebah penghasil madu sehingga sangat potensial untuk dikembangkan. Selain itu, banyak dijumpai lebah Trigona $S p$. yang hidup dan bersarang secara liar yang dijumpai di lingkungan sekitar masyarakat yang tinggal di tiga zona pemanfaatan tersebut.

\section{b. Pembinaan dan pelatihan budidaya lebah madu}

Telah dilakukan pembinaan dan pemberdayaan terhadap masyarakat sekitar kawasan terutama untuk budidaya lebah madu Trigona Sp. yang berdasarkan pengamatan disekitar kawasan sangat berpotensi untuk dikembangkan. Kegiatan pengenalan dan pelatihan dilakukan terhadap seluruh kelompok tani binaan di sekitar kawasan TNBT dan masyarakat yang berada pada zona pemukiman di Kecamatan Kuok.

Kegiatan pelatihan budidaya lebah madu diberikan kepada masyarakat yang berada di dalam tiga zona pemanfaatan, seperti pemberian materi pembelajaran dan praktek lapangan. Materi pembelajaran yang diberikan mulai dari hulu hingga hilir, mulai dari pengenalan jenis-jenis lebah hingga pemanenan hasil budidaya lebah madu. Sedangkan kegiatan praktek lapangan yang diberikan seperti pembuatan kotak budidaya, pemanenan dan cara mendapatkan koloni dari alam.

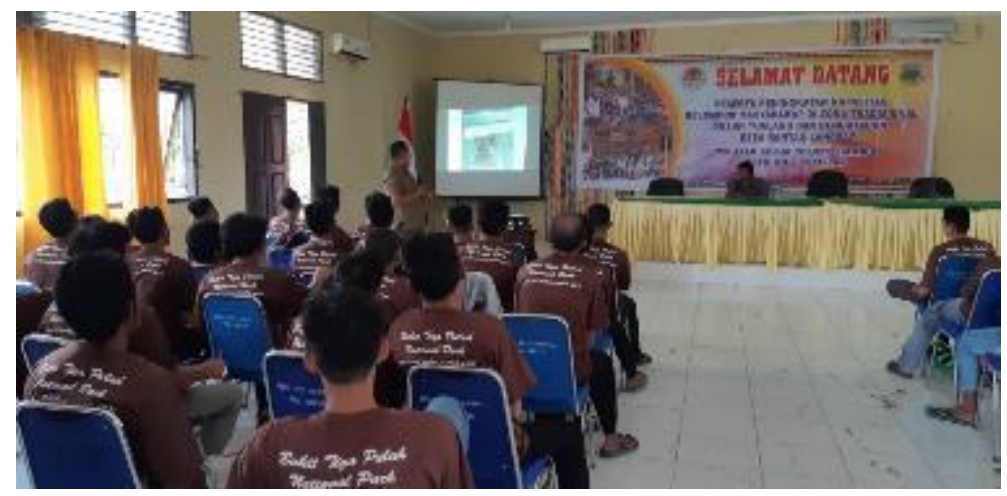

Gambar 2. Kegiatan pelatihan budidaya lebah madu

Kegiatan pembinaan dilakukan dengan kerjasama antara Peneliti perlebahan BP2TSTH Kuok dengan Penyuluh TNBT. Selain memberikan pembinaan dan pendampingan secara intensif, juga diberikan bantuan kepada kelompok masyarakat. Bantuan diberikan kepada kelompok masyarakat di masing-masing zona pemanfaatan berupa koloni lebah penghasil madu. Kelompok masyarakat zona tradisional diberikan sebanyak 75 koloni, zona penyangga sebanyak 71 koloni dan zona pemukiman sebanyak 20 koloni.

\section{c. Hasil pengabdian masyarakat}

Berdasarkan hasil pengamatan, diperoleh data produksi dari koloni lebah dalam kurun waktu 4 (empat) bulan sejak Januari - April 2019 yaitu: 
Tabel 2. Hasil panen madu di tiga zona pemanfaatan

\begin{tabular}{ccccc}
\hline No & $\begin{array}{c}\text { Zona Pemanfaatan } \\
\text { (Utilization zones) }\end{array}$ & $\begin{array}{c}\text { Produksi/ botol 200 ml } \\
\text { (Production) }\end{array}$ & $\begin{array}{c}\text { Berat Madu } \\
\text { (Honey weight) }\end{array}$ & $\begin{array}{c}\text { Jumlah Kotak } \\
\text { (Number of boxes) }\end{array}$ \\
\hline $1 \quad \begin{array}{l}\text { Zona Tradisional } \\
(\text { Traditional Zone) }\end{array}$ & 53,5 & $10,7 \mathrm{~kg}$ & 44 \\
$2 \begin{array}{l}\text { Zona Penyangga } \\
(\text { Buffer Zone) }\end{array}$ & 21,5 & $4,3 \mathrm{~kg}$ & 13 \\
\hline $\begin{array}{l}\text { Zona Pemukiman } \\
\text { (Residential zone) }\end{array}$ & 8,5 & $1,7 \mathrm{~kg}$ & 67 \\
\hline Jumlah (Total) & 83,5 & $16,7 \mathrm{~kg}$ & 6 \\
\hline
\end{tabular}

Sumber: Tim monitoring TNBT dan hasil analisis

Berdasarkan data tersebut, diperoleh data hasil panen madu lebah Trigona Sp. dari tiga zona pemanfaatan berbeda yaitu sebanyak 83,5 botol produksi (ukuran $200 \mathrm{ml}$ ) dengan berat madu sebanyak 16,7 kg dan jumlah koloni panen sebanyak 67 koloni. Pada tabel 2 diperoleh hasil bahwa panen madu terbanyak terdapat pada budidaya lebah di zona tradisional yaitu sebanyak $10,7 \mathrm{~kg}$ dari 44 kotak budidaya yang berhasil dipanen. Namun, dibandingkan ke tiga zona pemanfaatan, zona tradisional mendapatkan bantuan koloni lebih banyak dibandingkan dengan zona lainnya. Perbandingan yang dihasilkan dari budidaya lebah madu di tiga zona pemanfaatan yang berbeda dapat dilihat pada diagram berikut:

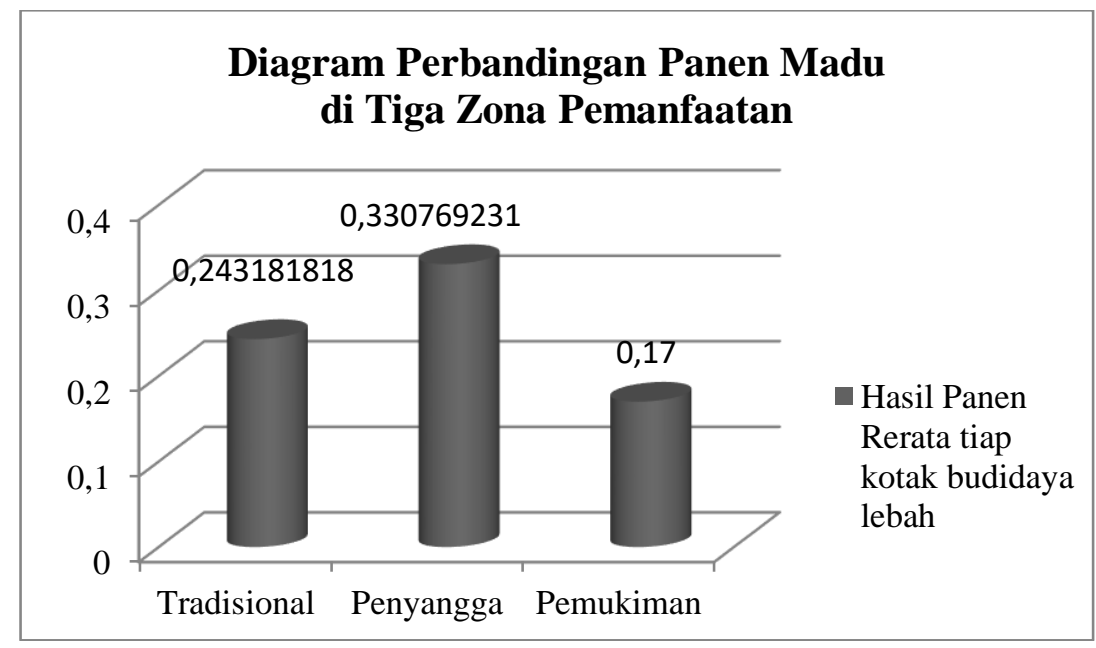

Gambar 3. Diagram perbandingan produksi madu di tiga zona pemanfaatan

Berdasarkan hasil analisis yang tertera di gambar 3, menunjukkan bahwa hasil panen rerata tiap kotak budidaya di tiga zona pemanfaatan terbanyak terdapat pada hasil panen kotak budidaya di zona penyangga sebanyak $0,33 \mathrm{~kg} / \mathrm{kotak}$. Kondisi lingkungan yang sudah berubah peruntukan dan didominasi oleh tanaman kelapa sawit membuat lahan menjadi terbuka. Sehingga tumbuhan bawah seperti tanaman yang menghasilkan bunga yang merupakan sumber pakan penghasil nektar dan polen bagi lebah dapat tumbuh dengan cepat.

Selain itu, cuaca berperan penting dalam proses penyerbukan. Misalnya ketika tiba-tiba terjadi hujan deras maka tepung sari akan berkurang dan berdampak pada jumlah madu yang dihasilkan. 


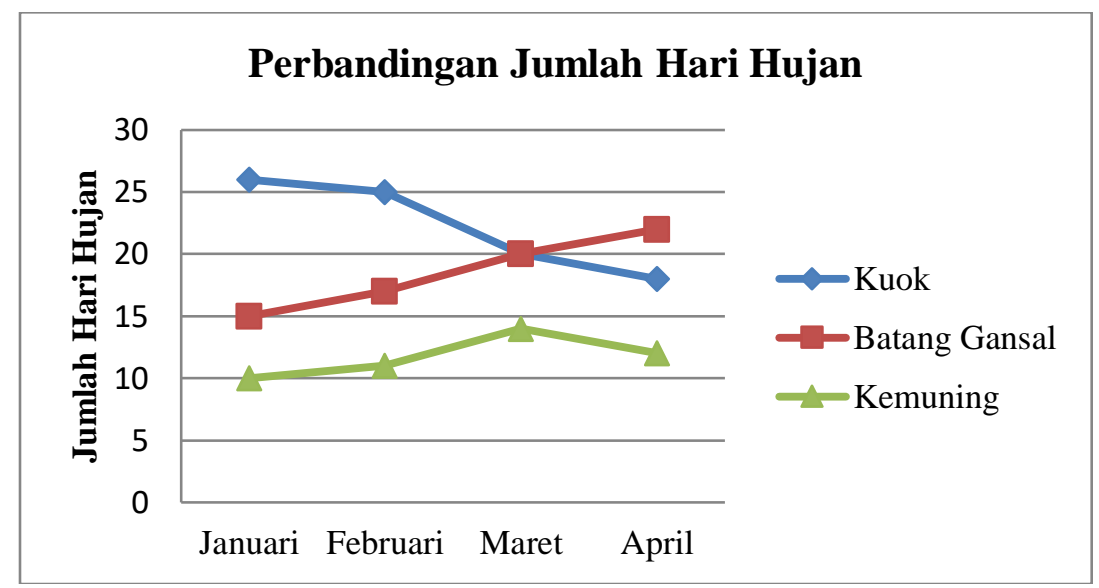

Gambar 4. Diagram perbandingan produksi madu di tiga zona pemanfaatan

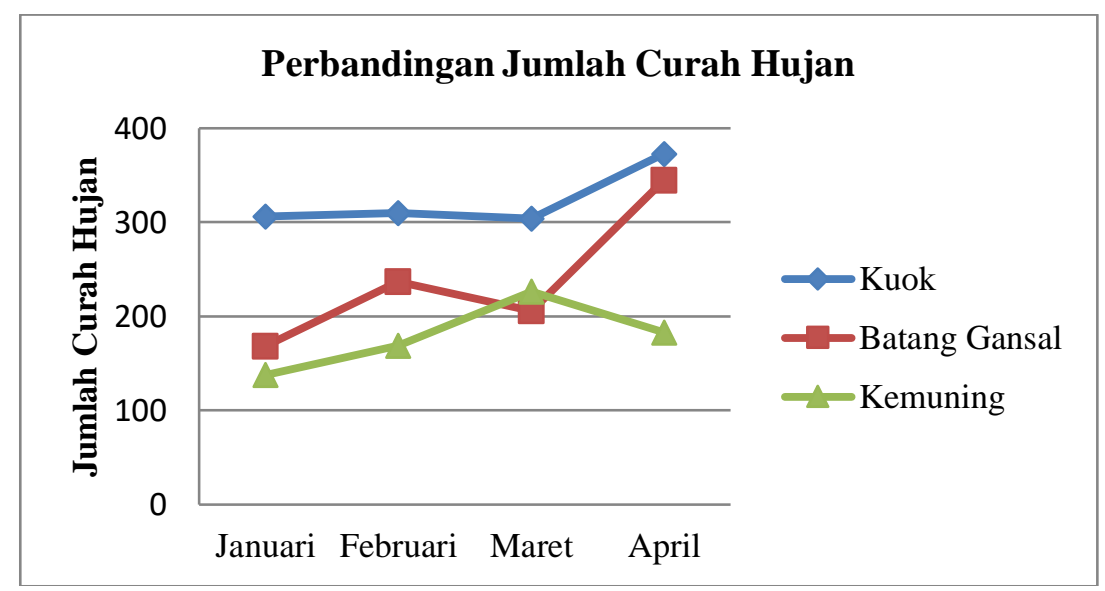

Gambar 5. Diagram perbandingan jumlah curah hujan di tiga zona pemanfaatan

Berdasarkan gambar 4 dan 5 diatas menunjukkan bahwa jumlah hari hujan dan curah hujan terendah dalam kurun waktu 4 bulan pengamatan terdapat pada zona penyangga dan tertinggi terdapat pada zona pemukiman. Pengaruh hujan terhadap tepungsari yang merupakan pakan lebah untuk menghasilkan madu terlihat pada hasil panen yang diperoleh. Curah hujan yang rendah di zona penyangga berdampak pada perolehan hasil madu yang lebih banyak. Sedangkan curah hujan tinggi di zona pemukiman berdampak pada perolehan madu yang lebih sedikit.

Total produksi madu untuk tiga zona pemanfaatan adalah sebanyak $16,7 \mathrm{~kg}$ dari 67 koloni produktif. Masih terdapat 99 koloni yang sangat potensial untuk menjadi koloni produktif. Nilai ekonomi yang diperoleh masyarakat dari penjualan madu adalah sebesar Rp. 60.000 /200gr/botol di zona tradisional, Rp. 50.000 $1200 \mathrm{gr} /$ botol di zona penyangga dan zona pemukiman. Dari panen madu lebah produktif, masyarakat zona tradisional dalam kurun waktu empat bulan memperoleh pendapatan tambahan sebesar Rp. 2.675.000, zona penyangga sebesar Rp. 1.290.000 dan zona pemukiman sebesar Rp. 425.000.

\section{d. Upaya pelestarian lingkungan}

Untuk menghindari terjadinya penurunan populasi lebah yang umumnya terjadi akibat banyaknya pertanian dengan satu jenis tanaman atau monokultur. Perlu mengkampanyekan sistem agroforestri untuk menambah ragam pakan lebah, biodiversitas yang menguntungkan dan menyeimbangkan alam (Suriyani, 2016). Selain itu, perubahan iklim dan kejadian karhutla juga dapat menyebabkan penurunan populasi lebah karena lebah memilih untuk migrasi ke daerah lain. Pola pelibatan masyarakat dalam pengelolaan kawasan hutan perlu dilakukan agar masyarakat dapat memperoleh manfaat keberadaan kawasan hutan sekaligus menjaga kelestarian kawasan.

Lebah hutan hanya mampu bersarang di kawasan hutan yang kondisi hutannya masih terjaga. Radius lebah mampu mencari makan hanya sekitar $3 \mathrm{Km}$ dari tempat mereka bersarang. Jadi, apabila di suatu daerah terdapat koloni lebah hutan dan masyarakat memperoleh intensif langsung dari hasil madu tersebut, dapat 
dipastikan masyarakat akan menjaga kawasan hutan dan areal lainnya yang menjadi tempat lebah mencari sumber pakan seperti nektar dan polen. Selain itu, juga untuk menghindari ancaman pengrusakan hutan, pembakaran hutan, penebangan liar, maupun alih fungsi lahan (Virgianti, 2013).

\section{e. Faktor pendukung dan penghambat pengabdian masyarakat}

Faktor pendukung pelaksanaan program pengabdian masyarakat dapat berjalan lancar sesuai dengan rencana karena adanya kerjasama saling bersinergi dengan baik antara tim peneliti, pengelola kawasan, pemerintah desa, penyuluh dan masyarakat setempat. Keberhasilan pelaksanaan program pengabdian masyarakat ini juga dipengaruhi oleh faktor potensi sumberdaya alam yang terdapat di lokasi pengabdian yang dikembangkan secara produktif dan inovatif oleh masyarakat desa hutan.

Sedangkan akar permasalahan dalam pengabdian masyarakat adalah rendahnya kualitas sumberdaya manusia masyarakat sekitar kawasan hutan yang dapat mempengaruhi tingkat kesadaran masyarakat dalam mengembangkan dan memanfaatkan potensi yang ada di sekitar mereka.

\section{KESIMPULAN}

Proses pemberdayaan masyarakat sekitar kawasan hutan sudah berjalan dengan baik. Hal ini dapat terlihat dari minat masyarakat yang tinggi untuk memberdayakan dirinya dan mengembangkan potensi yang mereka miliki. Adanya kegiatan pemberdayaan masyarakat melalui budidaya lebah madu membuat masyarakat memiliki kegiatan yang bermanfaat bukan hanya untuk dirinya sendiri, tetapi juga lingkungan sekitar karena turut serta menjaga kelestarian lingkungan. Kegiatan tersebut juga mampu meningkatkan pendapatan masyarakat. Tentunya terdapat hambatan dalam melakukan kegiatan ini yaitu rendahnya kualitas sumberdaya manusia masyarakat sekitar kawasan hutan yang dapat mempengaruhi tingkat kesadaran masyarakat dalam mengembangkan dan memanfaatkan potensi yang ada di sekitar mereka. Dengan adanya permasalahan ini, diperlukan tindakan khusus untuk meningkatkan kualitas sumberdaya manusia berupa pendidikan dan pelatihan tambahan serta pendampingan lebih intensif terhadap pelaksanaan kegiatan selanjutnya.

\section{UCAPAN TERIMA KASIH}

Ucapan terimakasih disampaikan kepada Kepala Balai BP2TSTH Kuok dan Balai TNBT beserta jajarannya atas sumbang saran dan bantuan yang besar terhadap kegiatan pengabdian masyarakat ini. Tim Penelitian Sosial, Ekonomi dan Kebijakan BP2TSTH Kuok atas bantuannya selama pengambilan data di lapangan serta penulisan naskah, serta masyarakat sekitar kawasan yang turut berperan aktif di dalam kegiatan pengabdian ini.

\section{DAFTAR PUSTAKA}

Ali, M., Melay, R., \& Bunari. 2019. The Existence of Kampar Malays in Riau Province Case Study: Koto Limo Area, Kampar Regency. Jurnal Online Mahasiswa, 6(1), 1-14.

Anonim. 2006. Laporan Profil Desa di Kecamatan Kemuning. Program Pengelolaan Terpadu Bukit Tigapuluh. KKI WARSI. Jambi.

Anonim. 2019. Kebakaran hutan dan lahan kian meluas dan kabut asap semakin parah, BNPB kewalahan padamkan api. BBC News Indonesia. https://www.bbc.com/indonesia/indonesia-49708970

Baskoro, B., Kamarudin, Karokaro, A. S., Rakhman, F., Apriando, T., \& Arumingtyas, L. 2019. Hutan Negeri Masih Hadapi Berbagai Keterancaman - Mongabay.co.id. Mongabay. https://www.mongabay.co.id/2019/03/21/hutannegeri-masih-hadapi-berbagai-keterancaman/amp/

Ekarina. 2019. BNPB Catat 328.724 Hektare Hutan dan Lahan Terbakar hingga Agustus. Katadata.co.id. https://katadata.co.id/ekarina/berita/5e9a4e6ceeff9/bnpb-catat-328724-hektare-hutan-dan-lahan-terbakar-hinggaagustus

Matatula, J. 2009. Upaya Rehabilitasi Lahan Kritis Dengan Penerapan Teknologi Agroforestry Sistem Silvopastoral Di Desa Oebola Kecamatan Fatuleu Kabupaten Kupang. Inotek, 13(1), 63-74.

Novandra, A., \& Widnyana, I. M. 2013. Peluang Pasar Produk Perlebahan Indonesia. In Alih Teknologi Balai Penelitian Teknologi Hasil Hutan Bukan Kayu.

PPID KLHK. 2018. KLHK Tingkatkan Rehabilitasi Hutan dan Lahan Sepuluh Kali Lipat di 2019. PPID KemenLHK. https://ppid.menlhk.go.id/siaran_pers/browse/1723 
Suriyani, L. De. 2016. Begini Ide Adopsi untuk Pelestarian Lebah dan Peningkatan Produksi Madu. Mongabay. https://www.mongabay.co.id/2016/10/06/begini-ide-adopsi-untuk-pelestarian-lebah-dan-peningkatan-produksimadu/

Ulya, N. A., Waluyo, E. A., \& Premono, B. T. 2016. Partisipasi Masyarakat dalam Rehabilitiasi Hutan Lahan Basah di Kabupaten Banyuasin. In Bunga Rampai Pengelolaan Lahan dan Air Berkelanjutan Dengan Melibatkan Masyarakat (Vol. 2, Issue February 2018).

Virgianti, K. 2013. Madu Hutan Sebagai Upaya Pelestarian Area Hutan dan Alternatif Pendapatan Masyarakat Lokal. Satu Harapan. http://www.satuharapan.com/read-detail/read/madu-hutan-sebagai-upaya-pelestarian-area-hutandan-alternatif-pendapatan-masyarakat-lokal

Widiarti, A., \& Kuntadi. 2012. Budidaya Lebah Madu Apis mellifera L. Oleh Masyarakat Pedesaan Kabupaten Pati, Jawa Tengah. Jurnal Penelitian Hutan Dan Konservasi Alam, 9(4), 351-361.

Wiratno. 2017. Tantangan Perhutanan Sosial dan Peran CSO. Kata Pengantar pada Prosiding Lokakarya "Strategi Penguatan Perhutanan Sosial dan Peran CSO. Trobenbos Indonesia. Bogor.

Wollenberg, E., B. Belcher, D. Sheil, S. Dewi dan M. Moeliono. 2004. Mengapa kawasan hutan penting bagi penanggulangan kemiskinan di Indonesia? Governance Brief Desember 2004. Cifor. Bogor

Yunianto, A. S. 2020. Empowerment effort for surrounding forest community living in the buffer zone and traditional zone at Bukit Tigapuluh National Park (BTNP). IOP Conference Series: Earth and Environmental Science, 533. https://doi.org/10.1088/1755-1315/533/1/012027 